\title{
An Update On Budgetary Participation, Locus Of Control, And The Effects On Mexican Managerial Performance And Job Satisfaction
}

\author{
Maria A. Leach-López, Auburn University Montgomery \\ William W. Stammerjohan, Louisiana Tech University \\ John T. Rigsby Jr., Mississippi State University
}

\begin{abstract}
This study examines the effects of budgetary participation, and the personality variable, locus of control, on the performance and job satisfaction of Mexican managers working for US controlled maquiladoras on the US/Mexican border and within interior Mexico. This study follows the methodology employed by Frucot and Shearon (1991), finds similar empirical results, but reaches quite different interpretations and conclusions. While Frucot and Shearon interpreted their results as suggesting caution in the use of participative budgeting by US companies operating in Mexico, we find that Mexican managers working for US controlled maquiladoras in Mexico may exhibit cultural values much like their US counterparts and that the performance of these Mexican managers may benefit from budgetary participation.
\end{abstract}

Keywords: budget participation, performance, job satisfaction, locus of control, job relevant information, cultural study.

\section{INTRODUCTION}

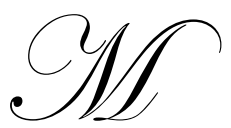

anagement is always about people, "it is part of the culture of the society in which it takes place" (Hofstede 2007, p. 413). Hofstede argues against beliefs held by, what he calls, the "popular management literature." The popular management literature assumes that management problems change over time, but that these management problems are the same across the world. According to Hofstede, 'popular management' research follows the latest trends. Hofstede defends an opposite viewpoint. He believes that management problems are the same over time, but the solutions differ from one part of the world to another and from country to country (Hofstede 1999, 2007). Popular management has concluded that if "Western management principles don’t work somewhere, this is not the fault of the principles but of the people" (2007, p.412).

Using the work of Hofstede (1980, 1983) for hypotheses development, Frucot and Shearon (1991) measured the effect of budget participation on job performance and job satisfaction of Mexican managers. Using regression, Frucot and Shearon (F\&S) tested the interrelationship of budget participation and locus of control (a personality variable) and their impact on job performance and job satisfaction. They assumed that an organizational system such as budget participation would have different effects in different cultures. They extended prior research by Brownell $(1981,1982 a)$ who found that a manager's personality would mediate the effects that the budget participation process would have on job performance and job satisfaction.

Frucot and Shearon (1991) theorized that culture might be an important variable in the budget participationperformance and budget participation-job satisfaction relationships. They utilized Hofstede's $(1980,1983)$ cultural value results but did not measure the cultural dimensions of their sample. Although F\&S's hypotheses are two- 
sided, their implied expectations are that the cultural differences between the US and Mexico documented by Hofstede (1980) should reduce the benefits of participative budgeting in Mexico. F\&S concluded that the lack of significance in their variables was due to cultural differences despite the fact that they only included Mexican managers in their sample. F\&S suggested that foreign owned firms "may wish to exercise caution when applying participative budgeting techniques in Mexico (p. 96)." F\&S's admonitions are mostly directed to maquiladora firms even though no maquiladoras were included in their sample.

The findings of Frucot and Shearon and the subsequent passage of NAFTA have left several unanswered questions. (1) Can US parent companies expect budget participation to affect the job performance and job satisfaction of their Mexican managers in US controlled maquiladoras? (2) Are there significant cultural differences between Mexican managers currently employed by US controlled maquiladoras and their US counterparts? And, (3) do these cultural differences, if they exist, lead to differences in the participation-performance and participation-job satisfaction relationships when US managers working in the US are compared with Mexican managers working for US controlled maquiladoras? The purpose of our study is to address these questions.

The remainder of this paper is organized as follows: Section II describes Frucot and Shearon's model and findings. Section III includes a brief description of Hofstede's (1980) cultural dimensions. Section IV describes our research design, hypotheses tests, and a description of variables used. Section V reports our results. Section VI provides the conclusions, limitations, and suggestions for future research.

\section{F\&S MODEL AND FINDINGS}

While there is a large body of prior research on the relationship between budget participation and performance, and while the effects of management techniques employed in Asia have received considerable attention (e.g., Birnberg and Snodgrass 1988; Harrison 1992; Ueno and Sekaran 1992; Harrison et al. 1994; Chow et al. 1991, 1994, 1996, 1999), Frucot and Shearon (1991) and Leach-López et al. (2007) are the only studies that examine the effects of participative budgeting within Mexico.

Frucot and Shearon's implied expectations are that the cultural differences between the US and Mexico documented by Hofstede (1980) should reduce the benefits of participative budgeting in Mexico. F\&S focused their study on budgetary participation in an attempt to examine the cross-cultural generalizability of Brownell's (1982a) findings in the US. Brownell identified the relationship between locus of control (a personality variable) and participation in the budgeting process as it impacts managerial performance and satisfaction. F\&S hypothesized that Brownell's results might not generalize to Mexico because Mexican society was ranked by Hofstede (1980) as higher on power distance and uncertainty avoidance than the US, and that high rankings on these dimensions would be associated with a preference for an autocratic, rule-based organization, and for less participation.

F\&S used managers from Mexico City working for 21 different companies. Of the companies represented in their study, only nine were in manufacturing. And yet, their conclusions were addressed towards the maquiladora system. It must be remembered that maquiladoras are manufacturing firms in that only value added activities can be performed in the maquiladoras plant, i.e. manufacturing. The companies in F\&S's study include seven service companies, two holding companies, nine in manufacturing, one merchandising, and one with merchandising and services characteristics. They selected their sample by contacting three Mexico City banks that put one of the authors in touch with higher-level managers within the selected firms. These higher-level managers selected individual managers for participation in this study. The questionnaires were personally distributed and later collected from the 86 managers involved in the study.

F\&S do not directly measure the effects of culture. They compare their Mexican results to prior studies conducted in the US to infer the effects of culture. Contrary to their implied expectations, Frucot and Shearon find positive relationships between budget participation and performance and between budget participation and job satisfaction. However, on further review they find these relationships to only be significant among managers that report directly to the highest level of the organization and among managers working for companies with partial Mexican ownership. 
Brownell (1982a) utilized locus of control to measure the personality of managers. He found that US managers are generally classified as internals in the locus of control construct. Frucot and Shearon (1991) hypothesized that the Mexican managers would tend to be classified as external in this personality variable, meaning that, as external personalities, these managers would prefer an autocratic structure as opposed to preference for participation in budget development.

F\&S found that the overall performance of the sample managers was associated with both locus of control and participation, thus concluding that no culture effect was present for performance. They did find that participation is related to salary increases, but locus of control did not affect salary increases significantly. Frucot and Shearon (1991) concluded that participation alone positively affects the overall satisfaction of the Mexican managers and that internals are not significantly more satisfied with high budgetary participation. The majority of the 83 Mexican managers surveyed were classified as internals. Frucot and Shearon found that personality is not a moderating variable in the participation-satisfaction relationship. This result is different from Brownell (1982a) and Frucot and Shearon attributed this difference to cultural differences.

\section{CULTURAL DIMENSIONS}

Frucot and Shearon (1991, p. 85) expect budget participation to be less beneficial to performance among Mexican managers because of the high power distance and high uncertainty avoidance documented by Hofstede (1980). Harrison and McKinnon (1999, pp. 494-496) indicate that high collectivism should be associated with a preference for participation. Sivakumar and Nakata (2001, p. 556) find that "Mexican managers are more apt to use participatory management techniques than their American counterparts [and that] collectivism is said to engender this effect."

Hofstede (1980) identified, and labeled, four dimensions of culture: large versus small power distance, strong versus weak uncertainty avoidance, individualism versus collectivism, and masculinity versus femininity. These labels should not be viewed as stereotypes, but merely as what they are, labels.

\section{Large versus Small Power Distance}

Power distance (PDI) refers to the way in which societies handle the problem of human inequality. Hofstede (1980, p.92) provides evidence that in a large PDI society "close supervision [is] positively evaluated by subordinates." In a large PDI society, subordinate consultation may not be as important as in a small PDI society because there is a tendency for its members to accept paternalistic management (Perera and Mathews 1990). Opposite from the US, Mexico is classified as a large PDI society (Hofstede 1980), and thus Mexican managers would be expected to prefer a centralized management, and be averse to budget participation.

\section{Strong versus Weak Uncertainty Avoidance}

Uncertainty avoidance (UA) relates to the degree to which members of a society feel uncomfortable with uncertainty and ambiguity. A high UA society is one in which there is low tolerance for uncertainty and an aversion towards risk taking (Hofstede 1980). According to Perera and Mathews (1990), the fundamental issue involved in this dimension is how a society reacts to the fact that the future is not known; whether the society tries to control the future or just let it happen. Unlike the US, Mexico is classified as a high UA society, thus Mexican managers should prefer low budget participation.

\section{Individualism Versus Collectivism}

In a high individualistic society, people focus on themselves as individuals rather than on the group, or groups, to which they may belong. Under this perspective, an individual is seen as having an identity in and of him or herself, which is separable from, and is not dependent upon, a group affiliation (Hofstede 1980). According to Perera and Mathews (1990), in an individualistic society, the employer-employee relationship would tend to be calculative (benefit the individual), but in a collectivistic society this relationship would tend to be morally based 
(benefit the group). Opposite from the US, Mexico is classified as a collectivistic society (Hofstede 1980), so Mexican managers would be expected to prefer teamwork and team rewards.

\section{Masculinity Versus Femininity}

Masculinity represents a societal preference for achievement and assertiveness, for making money or enjoying material success. Femininity represents a preference for putting relationships with people before money, the quality of life, and preservation of the environment. This dimension draws attention to the existence within society of competitiveness as opposed to solidarity, and achievement motivation as opposed to relationship motivation. Some of the issues raised by this dimension are career expectations and acceptability of an autocratic manager (Perera and Mathews 1990). Both Mexico and the US are classified as High in the Masculinity dimension (Hofstede 1980).

\section{RESEARCH DESIGN}

Our extension of Frucot and Shearon (1991) is designed to concentrate on our specific interest in the management environment faced by US controlled maquiladoras. Our study differs from Frucot and Shearon in the following ways:

(1) While Frucot and Shearon measure culture by comparing their Mexican results against prior research conducted in the US, we employ both Mexican and US subjects to provide a more direct test of cultural differences.

(2) While Frucot and Shearon employ both high-level and mid-level managers from a wide variety of industries, we employ only mid-level managers working in manufacturing to focus on the maquiladora environment.

While Frucot and Shearon only use subjects from interior Mexico to infer the relationship between budget participation and performance for managers working in maquiladoras, the current study employs subjects working in maquiladoras located on the US-Mexican border and located in interior Mexico.

\section{Hypotheses}

Adler (1984) believes that research into a national culture should be replicated in order to increase our knowledge of culture's impact. Frucot and Shearon (1991) emphasize the importance of following an initial study's research method as closely as possible when extending or replicating prior studies in order to facilitate comparability. Our hypotheses follow those tested by F\&S, but unlike F\&S we state our hypotheses in the alternative form to clearly communicate our expectations. The cultural effects between our Mexican and US samples are tested by examining the differences in results between the two samples. If the cultural effect theorized by $F \& S$ is present, we would expect the results of our hypotheses tests to be generally weaker for our Mexican sample as compared to our US sample.

H1: The degree of participation in the budgetary process leads to higher performance.

H2: The degree of participation in the budgetary process leads to higher satisfaction.

H3: Locus of Control has, through an interaction effect with budgetary participation, a significant effect on performance.

H4: Locus of Control has, through an interaction effect with budgetary participation, a significant effect on job satisfaction.

Our first tests of hypotheses $\mathrm{H} 1$ and $\mathrm{H} 2$ are the simple correlations between budget participation (BPP) and performance (PER) and between budget participation and satisfaction (SAT) represented by models (1a) and (1b). All our models are estimated over standardized versions of our primary variables (BPP, PER, SAT, LOC), i.e., there are no intercepts. 


$$
P E R_{i}=\beta_{1} B P P_{i}+e_{i}
$$$$
S A T_{i}=\beta_{1} B P P_{i}+e_{i}
$$

An interaction term is added to model (1) to test hypotheses $\mathrm{H} 3$ and $\mathrm{H} 4$, the effect of personality. The expanded model is represented by models (2a) and (2b). The $\beta_{1}$ coefficients in these two models provide our second tests of hypotheses $\mathrm{H} 1$ and $\mathrm{H} 2$.

$$
\begin{aligned}
& P E R_{i}=\beta_{1} B P P_{i}+\beta_{2} L O C_{i}+\beta_{3}\left|B P P_{i}+L O C_{i}\right|+e_{i} \\
& S A T_{i}=\beta_{1} B P P_{i}+\beta_{2} L O C_{i}+\beta_{3}\left|B P P_{i}+L O C_{i}\right|+e_{i}
\end{aligned}
$$

where

PER is performance measured using the Mahoney et al. (1963) eight-item scale,

SAT is satisfaction measure using the MSQ by Weiss et al. (1967),

BPP is budget participation measured as the sum of the six-item scale developed by Milani (1975),

LOC is locus of control as measured using Rotter's (1962) Internal/External scale,

$|\mathrm{BPP}+\mathrm{LOC}| \quad$ is the interaction of budgetary participation and locus of control calculated to assign higher values to greater miss-matches, i.e., greater participation for externals and lesser participation for internals.

\section{Variables}

The data for this study were collected by having each mid-level manager complete a survey instrument that was written in either English or Spanish. Adequate translation of the instrument was accomplished by following the method suggested by Hui and Triandis (1985). The sample includes US managers working in the US and Mexican managers working for US controlled companies in Mexico (maquiladoras). Similar to Frucot and Shearon (1991), the hypotheses are tested using multiple regression analysis.

The level of budget participation (BPP) is measured with a six-item scale developed by Milani (1975). This measure sums each item score measured with a seven-point Likert-type scale. This scale has been widely used in participative budget research (e.g., Brownell 1982b, 1983; Chenhall and Brownell 1988; Mia 1989; Frucot and Shearon 1991; Leach-López et al. 2007).

Performance (PER) is a self reported measure based on an eight-dimension scale developed by Mahoney et al. (1963). The Mahoney et al. scale measures eight performance dimensions: planning, investigating, coordinating, evaluating, supervising, staffing, negotiating, and representing. PER is the sum of these eight individual measures. The appropriateness of using self-reported measures of performance and the reliability of the Mahoney et al. scale are well documented (Heneman 1974). This scale has been widely used in participative budgeting research (e.g., Brownell 1982a, 1983; Brownell and Hirst 1986; Brownell and McInnes 1986; Frucot and Shearon 1991; LeachLópez et al. 2007).

The level of job satisfaction (SAT) is measured with the short-form of the Minnesota Satisfaction Questionnaire (MSQ) (Weiss et al. 1967). Scarpello and Campbell (1983) judged the MSQ the most successful facet-based measure of predicting overall job satisfaction. The short-form version of the MSQ has been supported for its reliability and validity (Weiss et al. 1967), and has been used extensively in both applied psychology (e.g., Pulakos and Schmitt 1983; Butler 1983) and managerial accounting research (e.g., Brownell 1981, 1982a, 1982b; Harrison 1992, 1993; Leach-López et al. 2007). 
The locus of control personality variable (LOC) is measured with a refined version of the additive scale developed by Rotter et al. (1962). The refined scale includes filler items to disguise the purpose of the test (Phares 1976). Rotter et al. (1962) describes the "locus of control" dimension of personality construct as distributing individuals according to the degree to which they accept personal responsibility for what happens to them. Locus of control classifies the individual as either internal or external. In general, Leftcourt (1966) describes internal control as the perception of positive and/or negative events as being a consequence of one's own actions and thus under personal control. External control is described as the perception of positive and/or negative events as being unrelated to one's own behavior and thus beyond personal control.

For ease of interpretation, we measure BPP, PER and SAT so that higher scores are associated with higher levels, i.e., higher scores indicate higher levels of budget participation, job performance, and job satisfaction. We measure locus of control (LOC) so that higher scores are indicative of more external personalities.

The cultural dimensions scores for power distance (PDI), uncertainty avoidance (UAI), individualism (IDV), and masculinity (MAS) are calculated using Hofstede's VSM 94 (Hofstede 1994).

\section{RESULTS}

\section{Sample}

All of the subjects in this study are mid-level managers working for US manufacturing companies located in the US, or US controlled manufacturing companies located in Mexico. Each manager completed a survey instrument written in either English or Spanish. The 45 US subjects worked for 15 different manufacturing companies located in the southeastern US. These subjects were obtained by first gaining permission from the HR manager and then by sending the survey instruments to the HR manager by email for distribution to the mid-level managers. The US responses were collected via email sent directly to one of the authors.

The 49 border subjects are Mexican managers working for 20 US controlled maquiladoras located in, or near, Nuevo Laredo. The 40 interior subjects are Mexican managers working for 29 US controlled maquiladoras located in, or near, Puebla, a metropolitan city about 250 miles south of Mexico City. The Mexican subjects were obtained from lists of 39 active US controlled maquiladoras in the Nuevo Laredo region and 49 active US controlled maquiladoras near Puebla. These lists were provided by Mexico's Department of Commerce. The research instruments in the Mexican samples were hand delivered to the maquiladoras that agreed to participate and the completed instruments were hand collected a few days later. The responses were requested on a voluntary basis.

\section{Demographics}

Table 1 includes the gender, age, and education of the respondents in each sample (89 Mexican managers, 45 US managers). These demographics are reported to give the reader a sense of the similarities and differences between the samples. The Mexican sample includes a smaller portion of male managers (70\% vs. $87 \%$ ) and is younger (55\% under 40 as opposed to $27 \%$ under 40 ). The education levels are quite similar with $79 \%$ of Mexican managers and $84 \%$ of the US managers having attended college.

Table 2 presents the variable means and differences between them. The Mexican managers report a significantly higher level of self-reported performance and a marginally significant higher level of job satisfaction. The differences in budgetary participation and locus of control are not significant.

\section{Hypotheses $\mathrm{H1}$ and $\mathrm{H} 2$}

Table 3 reports the correlations between the model variables. Hypothesis H1, the direct relationship between budget participation and performance is supported by both samples. These results are consistent with the overall finding of Frucot and Shearon (1991) and consistent with the findings within the majority of the extant literature (Greenberg et al.1994). 
Although both dependent variables of performance (PER) and job satisfaction (SAT) are significantly correlated over both samples, hypothesis $\mathrm{H} 2$, the direct relationship between budget participation and job satisfaction is only supported over the Mexican sample. The Mexican results are consistent with the overall finding of Frucot and Shearon (1991).

Other interesting findings presented in Table 3 are the significant negative relationship between locus of control and performance and between locus of control and budgetary participation. It appears that those who feel in control, internals with lower LOC scores, participate more and perform better.

The regression results reported in Table 4 are consistent with the simple correlation results reported in Table 3. Hypothesis H1, the direct relationship between budgetary participation and performance is fully supported over both samples. Hypothesis $\mathrm{H} 2$, the direct relationship between budgetary participation and job satisfaction is fully supported over the Mexican sample and marginally supported over the US sample.

\section{Hypotheses $\mathrm{H3}$ and $\mathrm{H4}$}

Similar to Frucot and Shearon (1991) we find little support for hypotheses H3 and H4. While we find a significant main effect in the expected direction between locus of control (LOC) and performance (PER) for the Mexican sample, the only interaction coefficient that is marginally significant is in the satisfaction (SAT) regression over the US sample.

TABLE 1

\section{Demographics}

\begin{tabular}{|c|c|c|c|c|c|}
\hline & & \multicolumn{2}{|c|}{ Mexico } & \multicolumn{2}{|c|}{ US } \\
\hline & & $\mathrm{N}$ & $\%$ & $\mathrm{~N}$ & $\%$ \\
\hline & Respondents: & 89 & & 45 & \\
\hline \multirow[t]{3}{*}{ Sex: } & Male & 62 & 70 & 39 & 87 \\
\hline & Female & 27 & 30 & 5 & 11 \\
\hline & No response & 0 & 0 & 1 & 2 \\
\hline \multirow[t]{8}{*}{ Age: } & 24 or less & 4 & 4 & 0 & 0 \\
\hline & $25-29$ & 16 & 18 & 4 & 9 \\
\hline & $30-34$ & 13 & 15 & 2 & 4 \\
\hline & $35-39$ & 16 & 18 & 6 & 13 \\
\hline & $40-49$ & 23 & 26 & 11 & 24 \\
\hline & $50-59$ & 14 & 16 & 12 & 27 \\
\hline & $60+$ & 2 & 2 & 2 & 4 \\
\hline & No response & 1 & 1 & 8 & 18 \\
\hline \multirow[t]{5}{*}{ Education } & Up to $9^{\text {th }}$ grade & 4 & 4 & 0 & 0 \\
\hline & $10^{\text {th }}$ to $12^{\text {th }}$ & 11 & 12 & 3 & 7 \\
\hline & $\begin{array}{l}\text { Some } \\
\text { college/degreed }\end{array}$ & 43 & 48 & 27 & 60 \\
\hline & Post graduate & 28 & 31 & 11 & 24 \\
\hline & No response & 3 & 3 & 4 & 9 \\
\hline
\end{tabular}


TABLE 2

Comparison of variable means

\begin{tabular}{|c|c|c|c|c|c|c|c|c|c|}
\hline \multirow[b]{2}{*}{ Variable } & \multirow[b]{2}{*}{$\begin{array}{l}\text { Expected } \\
\text { Range }\end{array}$} & \multicolumn{3}{|c|}{ Mexico } & \multicolumn{3}{|c|}{ US } & \multicolumn{2}{|c|}{ Mexico vs. US } \\
\hline & & $\mathrm{n}$ & Mean & $\begin{array}{l}\text { Actual } \\
\text { Range }\end{array}$ & $\mathrm{n}$ & Mean & $\begin{array}{l}\text { Actual } \\
\text { Range }\end{array}$ & $\begin{array}{l}\text { Mean } \\
\text { Difference }\end{array}$ & sig. \\
\hline PER & $8-72$ & 89 & 53.70 & $22-71$ & 45 & 50.27 & $21-66$ & 3.43 & 0.0455 \\
\hline SAT & $20-100$ & 89 & 73.85 & $44-96$ & 45 & 69.93 & $48-94$ & 3.92 & 0.0618 \\
\hline BPP & $6-42$ & 89 & 26.83 & $8-42$ & 45 & 25.60 & $10-42$ & 1.23 & n.s. \\
\hline LOC & $0-23$ & 89 & 7.07 & $0-20$ & 45 & 7.76 & $1-18$ & -0.69 & n.s. \\
\hline PER & \multicolumn{9}{|c|}{ Performance } \\
\hline SAT & \multicolumn{9}{|c|}{ Job satisfaction } \\
\hline BPP & \multicolumn{9}{|c|}{ Budgetary participation } \\
\hline LOC & \multicolumn{9}{|c|}{ Locus of control } \\
\hline
\end{tabular}

TABLE 3

Simple correlations

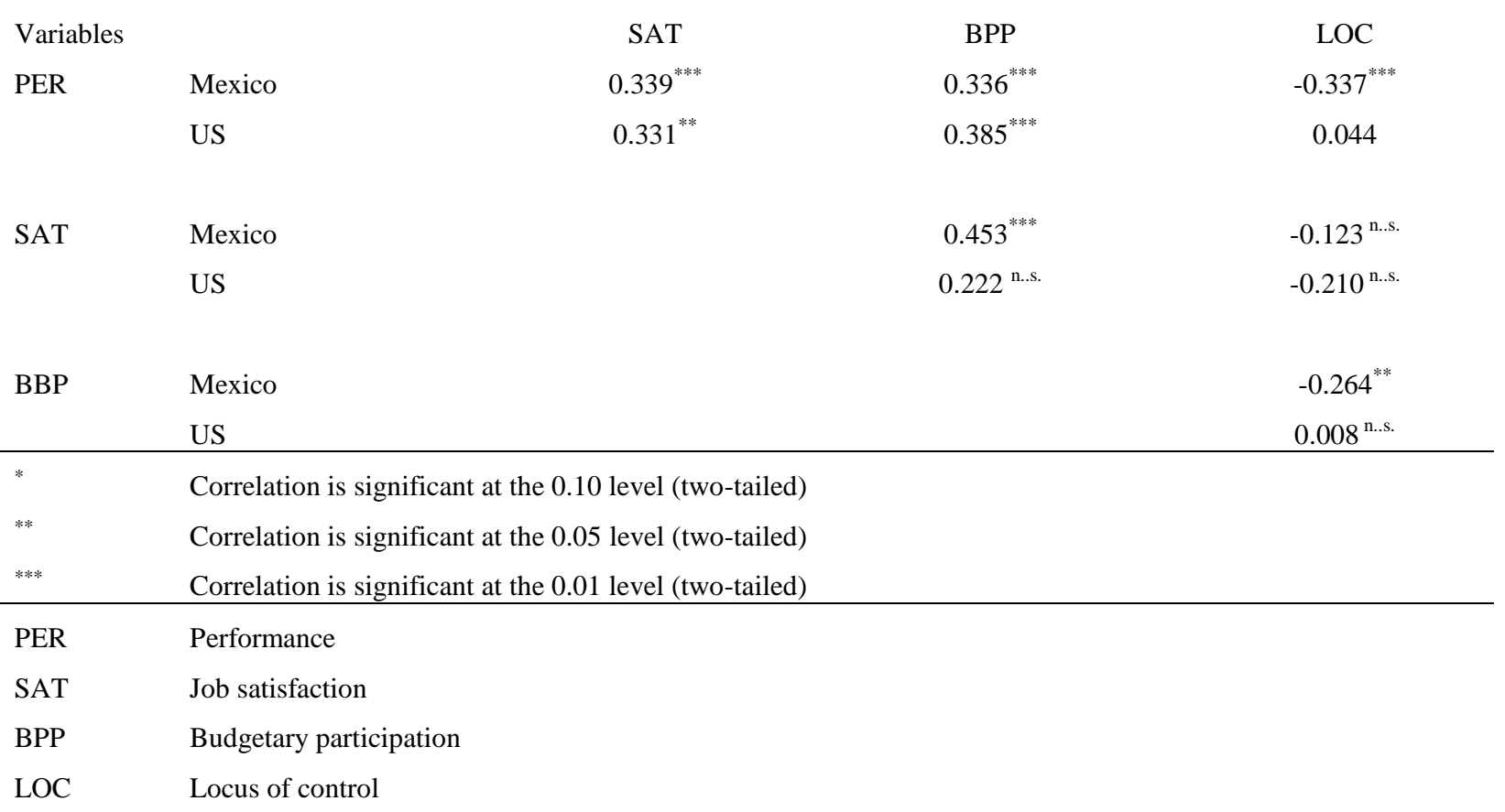




\section{TABLE 4}

\section{Regression results}

\begin{tabular}{llllllll} 
Mexican Sample & \multicolumn{1}{c}{} & & & & \\
& BPP & LOC & $|\mathrm{BPP}+\mathrm{LOC}|$ & $\mathrm{R}^{2}$ & $\mathrm{~F}$ & $\mathrm{p}$-value & d.f. \\
Expected sign & + & - & - & & & \\
PER & $0.267^{* * * *}$ & $-0.276^{* * *}$ & 0.047 & 0.181 & 6.25 & 0.001 & 85 \\
SAT & $0.446^{* * *}$ & -0.043 & 0.183 & 0.214 & 7.72 & 0.000 & 85
\end{tabular}

\begin{tabular}{|c|c|c|c|c|c|c|c|}
\hline \multicolumn{8}{|l|}{ US Sample } \\
\hline & $\mathrm{BPP}$ & LOC & $|\mathrm{BPP}+\mathrm{LOC}|$ & $\mathrm{R}^{2}$ & $\mathrm{~F}$ & p-value & d.f. \\
\hline Expected sign & + & - & - & & & & \\
\hline PER & $0.387^{* * *}$ & 0.058 & -0.068 & 0.153 & 2.47 & 0.076 & 41 \\
\hline SAT & $0.232^{*}$ & -0.139 & $-0.275^{*}$ & 0.142 & 2.25 & 0.097 & 41 \\
\hline * & \multicolumn{7}{|c|}{ Coefficient significant at the 0.10 level (one-tailed) } \\
\hline ** & \multicolumn{7}{|c|}{ Coefficient significant at the 0.05 level (one-tailed) } \\
\hline$* * *$ & \multicolumn{7}{|c|}{ Coefficient significant at the 0.01 level (one-tailed) } \\
\hline PER & \multicolumn{7}{|c|}{ Performance } \\
\hline SAT & \multicolumn{7}{|c|}{ Job satisfaction } \\
\hline BPP & \multicolumn{7}{|c|}{ Budgetary participation } \\
\hline LOC & \multicolumn{7}{|c|}{ Locus of control } \\
\hline$|\mathrm{BPP}+\mathrm{LOC}|$ & \multicolumn{7}{|c|}{$\begin{array}{l}\text { The interaction of budgetary participation and locus of control calculated in a way that assigns larger } \\
\text { values to greater miss-matches, i.e., greater participation for externals or less participation for } \\
\text { internals. }\end{array}$} \\
\hline
\end{tabular}

\section{Cultural Dimensions And Cultural Effects}

We report both the cultural dimensions for Mexico and the US as originally reported in Hofstede (1980) and relied upon by Frucot and Shearon (1991); and the cultural dimensions over our Mexican and US samples calculated using Hofstede's VSM 94 (Hofstede 1994) in Table 5. While our US results are quite similar to those reported by Hofstede (1980), our Mexican sample is much lower in power distance (PDI) and much higher on individualism (IDV) than the original Hofstede results.

We do not find signs of a significant cultural effect between our Mexican and US samples over the most important relationship in our study, the relationship between what companies can control - the level of budgetary participation - and what companies are looking for as the main outcome: higher performance. 
TABLE 5

\section{Cultural Dimensions}

\begin{tabular}{|c|c|c|c|c|c|c|c|c|c|}
\hline \multirow{2}{*}{\multicolumn{2}{|c|}{ Mexico per Hofstede * }} & \multicolumn{2}{|c|}{ PDI } & \multicolumn{2}{|c|}{ UAI } & \multicolumn{2}{|c|}{ IDV } & \multicolumn{2}{|c|}{ MAS } \\
\hline & & 81 & High & 82 & High & 30 & Low & 69 & High \\
\hline \multicolumn{2}{|c|}{ Mexico sample } & 29 & Low & 48 & Low & 72 & High & 83 & High \\
\hline \multicolumn{2}{|c|}{ US per Hofstede * } & 40 & Low & 46 & Low & 91 & High & 62 & High \\
\hline \multicolumn{2}{|c|}{ US sample } & 31 & Low & 33 & Low & 95 & High & 70 & High \\
\hline \multicolumn{10}{|c|}{$*$ Hofstede (1980) } \\
\hline \multicolumn{10}{|c|}{$\begin{array}{ll}\text { PDI } & \text { Power Distance }\end{array}$} \\
\hline \multicolumn{10}{|c|}{ UAI Uncertainty avoidance } \\
\hline \multicolumn{10}{|c|}{ IDV Individualism } \\
\hline MAS & Masculinity & & & & & & & & \\
\hline
\end{tabular}

\section{CONCLUSIONS, LIMITATIONS AND FUTURE RESEARCH}

Frucot and Shearon (1991) report the results of fifteen regression estimations. Ten of these use two different measures of performance as the dependent variable and the other five use a measure of job satisfaction as the dependent variable. These estimations are run over five samples (sub-samples): full sample, high-level managers, other-managers, less than $100 \%$ foreign ownership, and $100 \%$ foreign ownership. Based on a significant interaction coefficient for one measure of performance over the full sample and significant interaction coefficients for one measure of performance over the high-level manager sub-sample and over the less than $100 \%$ foreign ownership sub-sample, they conclude that culture played a role in their findings and that US companies "...may wish to exercise caution when applying participative budgeting techniques in Mexico" (p. 96).

While our Mexican empirical results are quite similar to those found in Frucot and Shearon (1991), our conclusions and interpretations are quite different. While Frucot and Shearon found at least marginally significant coefficients linking budget participation to performance for nine of the ten performance regressions and significant coefficients linking budget participation to job satisfaction for three of the five satisfaction regressions, they did not interpret these results as a positive sign that participative budgeting worked in Mexico.

While Frucot and Shearon (1991) relied on the prior work reported by Hofstede (1980) as evidence of cultural differences between Mexico and the US, we measured the cultural dimensions of our samples. While Frucot and Shearon expected that high power distance should diminish the benefits of participative budgeting in Mexico, neither their results nor our results provide contradictory evidence to this theory. Our cultural dimension results provide evidence that Mexican managers working for foreign companies may not fit Mexican cultural norms. It is quite possible that managers working for foreign companies may display cultural norms more like the company's home culture due to selection, assimilation, and/or retention. Furthermore, we interpret this result to suggest that US management techniques may work in situations where host country cultural norms may suggest otherwise.

Our study has common limitations found in this type of research. Each variable is measured with an established scale, but each of these scales contains some level of measurement error and each observation is dependant on the subject answering truthfully and accurately. There is also the potential weakness of using selfreported measures of budget participation and performance. Self-reported levels of participation may be more relevant than external measures of participation because it should be the subject's perception of budget participation that influences behavior. While external measures of performance have some documented benefits, self-reported measures of performance remain a common practice in the literature (Nouri and Parker 1998; Shields et al. 2000). Despite these acknowledged weaknesses, the findings of this study may have important implications for US firms doing business in Mexico. 
Given the importance of Mexico as a US trading partner, given the continued growth of maquiladora operations in Mexico, and given the scarce literature regarding effective management techniques for US controlled Mexican operations, we believe that our study provides some relevant and useful findings. Future research needs to determine whether maquiladoras have self-selected managers who mirror the US cultural dimensions, or whether the Mexican managers have become 'Americanized' through employment in US controlled firms. Future research also needs to determine whether the relationship between budget participation and performance and satisfaction is different for Mexican managers working for Mexican controlled firms with no foreign influence.

\section{BIOGRAPHIES}

Dr. Maria Leach - Before joining the world of academia, Dr. Leach worked with her husband in their construction business. Their two daughters, Heather and Megan, were born before Dr. Leach decided to pursue an academic career. She earned a bachelor of art degree in accounting from Mississippi University for Women in 1987. Dr. Leach attended Mississippi State University where she earned a Master of Professional Accountancy degree in 1988 and a Doctor in Business Administration degree in 2002. Dr. Leach is a Certified Public Accountant and a Certified Management Accountant. She has taught at Mississippi State University, Jackson State University, and Auburn Montgomery.

Dr. William Stammerjohan - After short careers as an owner-crew chief of a top fuel drag racing team and as a long-line truck driver, Dr. Stammerjohan spent 15 years as the owner-operator of a high-performance racing engine business in Sacramento, CA. Dr. Stammerjohan received his bachelor of science degree in business administration (accounting) from California State University - Sacramento in 1990 and his $\mathrm{PhD}$ from Washington State University in 1995. Dr. Stammerjohan has served on the faculties of: Mississippi State University, Washington State University, and Louisiana Tech University where he teaches intermediate financial accounting, advanced managerial accounting, and a doctoral seminar in financial accounting research.

Dr. John Rigsby - Currently an Associate Professor in the Richard C. Adkerson School of Accountancy at Mississippi State University. He has published over thirty articles in various areas, mainly in behavioral accounting. Some of the journals published in include: Managerial Auditing Journal, Behavioral Research in Accounting, Accounting, Auditing and Accountability Journal, Advances in Accounting, The British Accounting Review, Journal of Business Ethics, and the Journal of the American Taxation Association. Areas of interest published in include mentoring and peer relationships, managerial decision making, behavioral implications of modified audit reports, socialization of accountants, education and experience requirements for CPAs, and ethical codes of conduct.

\section{REFERENCES}

1. Adler, N. J. 1984. Understanding the ways of understanding: Cross-cultural management methodology reviewed. Advances in International Comparative Management. Ed. R. N. Farmer, JAI Press: 31-67.

2. Birnberg, J.G., and C. Snodgrass. 1988. Culture and control: A field study. Accounting, Organizations and Society 13: 447-464.

3. Brownell, P. 1981. Participation in budgeting, locus of control and organizational effectiveness. The Accounting Review 56 (October): 844-860.

4. 1982a. A field study examination of budgetary participation and locus of control. The Accounting Review 57 (October): 766-777.

5. _ 1982b. The role of accounting data in performance evaluation, budgetary participation and organizational effectiveness. Journal of Accounting Research (Spring): 12-27.

6. _ 1983. Leadership style, budgetary participation and managerial behavior. Accounting, Organizations and Society 8 (4): 307-321.

7. __ and M. K. Hirst. 1986. Reliance on accounting information, budgetary participation, and task uncertainty: Tests of a three-way interaction. Journal of Accounting Research (Autumn): 241-249.

8. _ and M. McInnes. 1986. Budgetary participation, motivation, and managerial performance. The Accounting Review 61 (October): 587-600. 
9. Butler, J. K. 1983. Value importance as a moderator of the value fulfillment-job satisfaction relationship: Group differences. Journal of Applied Psychology (August): 420-428.

10. Chenhall, R. H., and P. Brownell. 1988. The effect of participative budgeting on job satisfaction and performance: Role ambiguity as an intervening variable. Accounting, Organizations and Society 13 (3): 225-233.

11. Chow, C. W., M. D. Shields, and Y. K. Chan. 1991. The effects of management controls and national culture on manufacturing performance: An experimental investigation. Accounting, Organizations and Society 16 (3): 209-226

12. __ Y. Kato, and M. D. Shields. 1994. National culture and the preference for management controls: An exploratory study of the firm-labor market interface. Accounting, Organizations and Society 19 (4, 5): 381-400.

13. _ Y Y. Kato, and K. A. Merchant. 1996. The use of organizational controls and their effect on data manipulation and management myopia: A Japan vs. US comparison. Accounting, Organizations and Society 21 (2, 3): 175-192.

14. _ M. D. Shields, and A. Wu 1999. The importance of national culture in the design of and preference for management controls for multi-national operations. Accounting, Organizations and Society 24: 441461.

15. Frucot, V., and W. T. Shearon. 1991. Budgetary participation, locus of control, and Mexican managerial performance and job satisfaction. The Accounting Review 66 (January): 80-98.

16. Greenberg, P. S., R. H. Greenberg, and H. Nouri. 1994. Participative budgeting: A meta-analytic examination of methodological moderators. Journal of Accounting Literature 13: 117-141.

17. Harrison, G. L. 1992. The cross-cultural generalizability of the relation between participation, budget emphasis and job related attitudes. Accounting, Organizations and Society 17 (1): 1-15.

18. 1993. Reliance on accounting performance measures in superior evaluative style - The influence of national culture and personality. Accounting, Organizations and Society 18 (4): 319-339.

19. __ McKinnon, L, Panchapakesan, S., and Leung, M. 1994. The Influence of Culture on Organizational Design and Planning and Control in Australia and the United States Compared With Singapore and Hong Kong. Journal ofInternational Financial Management and Accounting 5: $242-261$.

20. __ and J. L. McKinnon. 1999. Cross-cultural research in management control systems design: A review of the current state. Accounting, Organizations and Society 24 (5/6): 483-506.

21. _ L_ L. McKinnon, S. Panchapakesan, and M. Leung. 1994. The influence of culture on organizational design and planning and control in Australia and the United States compared with Singapore and Hong Kong. Journal of International Financial Management and Accounting 5: 242-261.

22. Heneman, H. G. III. 1974. Comparisons of self and superior ratings of managerial performance. Journal of Applied Psychology 59 (5): 29-53.

23. Hofstede, G. H. 1980. Culture's Consequences: International Differences in Work-Related Values. Beverly Hills, CA: Sage Publications.

24. 1983. Dimensions of national cultures in fifty countries and three regions, in J. B. Deregowski, D. Dzuirawiec, and R. C. Annis, eds., Expectations in Cross-Cultural Psychology. Swets and Zeitlinger.

25. _. 1994. VSM94: Value survey module 1994. Available from http://feweb.uvt.nl/center/hofstede/english.html; accessed December 12, 2006.

26. 1999 . The universal and the specific in $21^{\text {st }}$-century global management. Organizational Dynamics 28 (1): 34-43.

27. 2007. Asian management in the $21^{\text {st }}$ century. Asia Pacific Journal of Management 24: 411-420.

28. Hui, C. H., and H. C. Triandis. 1985. Measurement in cross-cultural psychology: A review and comparison of strategies. Journal of Cross-Cultural Psychology 16 (June): 131-152.

29. Leach-López, M. A., W. W. Stammerjohan, and F.M. McNair. 2007. Differences in the role of job relevant information in the budget participation-performance relationship among US and Mexican managers: A question of culture or communication? Journal of Management Accounting Research. (19): 105-136.

30. Leftcourt, H. M. 1966. Internal versus external control of reinforcement: A review. Psychological Bulletin, April: 206-220.

31. Mahoney, T. A., T. H. Jerdee, and S. J. Carroll. 1963. Development of Managerial Performance: A Research Approach. South-Western Publishing, Co. 
32. Mia, L. 1989. The impact of participation in budgeting and job difficulty on managerial performance and work motivation: A research note. Accounting, Organizations and Society 14 (4): 347-357.

33. Milani, K. 1975. The relationship of participation in budget-setting to industrial supervisor performance and attitudes: A field study. The Accounting Review 50 (April): 274-284.

34. Nouri, H., and R. J. Parker. 1998. The relationship between budget participation and job performance: The roles of budget adequacy and organizational commitment. Accounting, Organizations and Society 23: 467483.

35. Perera, M. H. B., and Mathews, M. R. 1990. The cultural relativity of accounting and international patterns of social accounting. Advances in International Accounting Vol. III: 215-251.

36. Phares, E. J. 1976. Locus of Control in Personality. General Learning Press. Morristown, N.J.

37. Pulakos, E. D. and N. Schmitt. 1983. A longitudinal study of a valence model approach for the prediction of job satisfaction of new employees. Journal of Applied Psychology: 307-312.

38. Rotter, J. B., M. Seeman, and S. Liverant. 1962. Internal versus external control of reinforcements: A major variable in behavior theory, in N. F. Washburne (ed.). Decisions, Values and Groups. Pergamon Press: 473-516.

39. Scarpello, V. and J. P. Campbell. 1983. Job satisfaction: Are all the parts there? Personnel Psychology: 577-600.

40. Shields, M. D., F. J. Deng, and Y. Kata. 2000. The design and effects of control systems: Tests of directand indirect-effects models. Accounting, Organizations and Society 25: 185-202.

41. Sivakumar, K., and C. Nakata. 2001. The stampede toward Hofstede's framework: Avoiding the sample design pit in cross cultural research. Journal of International Business Studies 32 (Third Quarter): 555-574.

42. Ueno, S., and U. Sekaran. 1992. The influence of culture on budget control practices in the USA and Japan: An empirical study. Journal of International Business Studies 23 (4): 659-674.

43. Weiss, D. J., R. V. Davis, G. W. England, and L. H. Lofquist. 1967. Manual for the Minnesota Satisfaction Questionnaire. Minnesota Studies in Vocational Rehabilitation, Vol. XXII, October, Bulletin 45. 
NOTES 